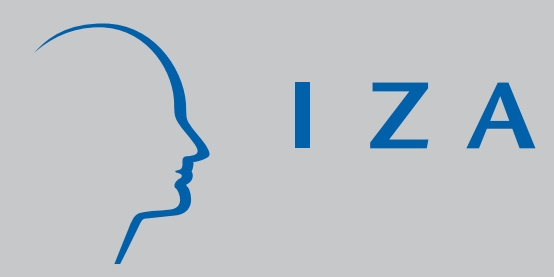

IZADP No. 2620

A New Regional Geography of Europe?

The Labour Market Impact of the EU Enlargements

Floro Ernesto Caroleo

Francesco Pastore

February 2007 


\title{
A New Regional Geography of Europe? The Labour Market Impact of the EU Enlargements
}

\author{
Floro Ernesto Caroleo \\ University of Naples Parthenope \\ Francesco Pastore \\ Seconda Università di Napoli and IZA
}

Discussion Paper No. 2620

February 2007

IZA

P.O. Box 7240

53072 Bonn

Germany

Phone: $+49-228-3894-0$

Fax: +49-228-3894-180

E-mail: iza@iza.org

\begin{abstract}
Any opinions expressed here are those of the author(s) and not those of the institute. Research disseminated by IZA may include views on policy, but the institute itself takes no institutional policy positions.

The Institute for the Study of Labor (IZA) in Bonn is a local and virtual international research center and a place of communication between science, politics and business. IZA is an independent nonprofit company supported by Deutsche Post World Net. The center is associated with the University of Bonn and offers a stimulating research environment through its research networks, research support, and visitors and doctoral programs. IZA engages in (i) original and internationally competitive research in all fields of labor economics, (ii) development of policy concepts, and (iii) dissemination of research results and concepts to the interested public.
\end{abstract}

IZA Discussion Papers often represent preliminary work and are circulated to encourage discussion. Citation of such a paper should account for its provisional character. A revised version may be available directly from the author. 


\section{ABSTRACT}

\section{A New Regional Geography of Europe? The Labour Market Impact of the EU Enlargements ${ }^{*}$}

This paper provides a critical overview and a detailed research agenda for scholars interested in regional studies with a special focus on old and new European Union member states. The focus is on the microeconomic foundations of structural change and its spatially asymmetric impact on labour markets. Structural change has been long neglected, but the availability of new data and the specific nature of economic transition in new member states has brought again this issue to the fore, suggesting that it might provide an explanation also of several typical features of regional imbalances in old member states. The literature provides theoretical reasoning and empirical evidence to confirm this.

JEL Classification: J6, P2, R1, R23

Keywords: regional unemployment, structural change, labour turnover, optimal speed of transition, EU enlargement

Corresponding author:

Francesco Pastore

Seconda Università di Napoli

Salita Tarsia 74

I-80135 Napoli

Italy

E-mail: fpastore@unina.it

\footnotetext{
* A previous version of this paper has circulated as call for papers of the XXII AIEL Conference. We thank Vera Adamchik, Francesca Bettio, Salvatore Capasso, Bruno Chiarini, Gianluigi Coppola, Sergio Destefanis, Anna Maria Ferragina, Elisabetta Marzano, Oreste Napolitano, Marcello Signorelli, Mieczyslaw Socha for comments on an earlier version of this paper. We also thank Giuliana Rando for careful English editing. However, the usual disclaimer applies.
} 


\section{Introduction}

The new century has brought unprecedented change to the economic and political geography of the European continent. Former socialist countries in Central Europe have already joined or are about to join the European Union. Other countries in Eastern Europe and the Balkans are likely to follow in the near future.

Most new member states have experienced the economic transition from a planned to a market economy. This has caused massive restructuring with dramatic and persistent labour market consequences. These dynamics are similar to those traditionally witnessed in the old backward regions of Southern Europe. The aim of this paper is to summarise research ideas and outcomes on how the changing political and economic map of Europe affects labour markets in both the old and new EU member states.

The specific focus of the discussion is on the microeconomic foundations of structural change and its spatially asymmetric impact on local labour markets. Structural change has been neglected for too long, but the availability of new data banks and the specific nature of economic transition in new member states has brought again this issue to the fore, suggesting that it might provide an explanation also of several typical features of regional imbalances in old member states. The literature recalled here provides much theoretical reasoning and empirical evidence to suggest that this might be the case.

Moreover, this study witnesses the changed perspective of research on regional imbalances on such issues as labour and capital migration. In the traditional way of thinking the migration of inputs was supposed to play an important part in the adjustment process causing convergence in the long run. In the more recent literature, migration is a cause of further divergence among advanced and backward regions. This is because higher returns to production factors are expected to happen in those regions where these factors already concentrate. Economies to scale, social returns to human capital explain this in turn.

The eastward enlargements of the EU will also have important policy implications. The increasing emphasis of the EU on antitrust law and the implementation of the Maastricht Treaty suggest refuting fiscal incentives. Moreover, the fact that most of the regions in the new member states are backward is bound to dramatically influence not 
only the institutional framework of the EU, but also regional policy. For instance, access and distribution conditions for Structural and Cohesion Funds will completely change.

The EU funds remain roughly of the same amount, but new member states claim their share. This implies more careful definition of the objectives and targeting of the interventions. Recent theories suggest to invest the EU funds to strengthen the endowment of human capital of backward regions. This implies innovation policy and investment in the educational sector. The only constant in the discussion about instruments of regional policy is the role of infrastructures.

The list of relevant themes dealt with and on which a detailed research agenda is laid down is as follows: a) the labour market impact of structural change; b) regional job and worker turnover; c) is migration reducing or reinforcing regional unemployment differences?; d) is there a regional dimension of gender differences?; e) human capital as a factor of regional convergence; $f$ ) the impact of trade and FDI on regional labour markets; g) hidden economy and hidden employment: micro- and macroeconomic implications; h) national and EU regional policy; i) benefit systems and their interaction with ALMP. Some concluding remarks follow

\section{A. The Labour Market Impact of Structural Change}

Structural change caused by a slump is often thought to have a cleansing effect, by pushing non-competitive firms out of the market. This is expected, in turn, to generate a reduction in employment and a consequent increase in productivity as soon as new more efficient firms are established (Caballero and Hammour, 1994).

This was also one of the main predictions of the benchmark Optimal Speed of Transition model for that particular type of structural change caused by the move from a centrally planned to a market based economy: newly established buoyant private firms were expected to reduce unemployment and raise the average productivity rate by absorbing low productivity workers fired from state-owned firms (Aghion and Blanchard, 1994).

In the old member states, regional labour market differences have further increased since the early 1980s as a consequence of the process of de-industrialisation and the 
move towards the post-fordist model of an economy based on advanced services. This implies a reshuffling of capital and labour resources from agriculture and large businesses operating in the traditional manufacturing sector to small firms in the ICT and advanced services sectors (Caroleo and Destefanis, 2006; Marelli, 2006). In the new member states, this process has been chaotic along with the move to a market economy.

In addition, all over the European continent, this process has led to a dramatic polarisation of economic activities and population to urban areas, which have grown in size as a consequence (EU, 2005). Development poles have emerged in the capital cities, causing a further impoverishment of rural areas, but the typical problems caused in the labour market by rapid urbanisation have also emerged: congested labour markets, need for additional social services, increased demand for education and training, and so on.

The prediction that structural change is conducive to increases in productivity has shown to be too optimistic. Extensive literature emphasises the massive size of the restructuring process itself, which was unable to be absorbed in a short time (Carlin and Mayer, 1992; Lehmann and Walsh, 1999; Berthold and Fehn, 2003; Marani, 2006; Newell and Pastore, 2006).

Moreover, labour hoarding in state-owned firms has remained sizeable for many years, especially in those new member states were the privatisation process has been slow. The social hardship of the transformation and the opposition of labour unions have been factors (Boeri, 2000). Despite increasingly hard budget constraints, stateowned firms have preferred to maintain unproductive workers, paying them via wage arrears and inter-firm loans (see, among others, Pinto, Drebentsov and Morozov, 2000; Stiglitz, 2001; Gara, 2001).

All these factors have slowed down the privatisation process. As noted in Marani (2006), the economic transition in the Eastern regions of Germany has also been slowed down by the federal government's attempt to expand the social market economy and to export the Western welfare system to the East without adapting it to the different context. This choice has caused dramatic consequences, including tensions about the state budget and the welfare system itself.

Moreover, unemployment had already reached two-digit levels in many transition countries in the mid-1990s, and still remains high. The reason for increasing 
unemployment is that structural change is painless when labour markets are frictionless. However, the labour market is tied to the free operation of market forces. Extensive literature highlights, among other things, the role of rigid wages and legislation protecting employment, non-employment subsidies and early retirement schemes as factors affecting labour supply decisions (see, among others, Boeri, 2000; World Bank, 2001; Rutkowski and Przybila, 2002; Funck and Pizzati, 2002; 2003).

The evolution of labour markets in New Member States is of utmost interest not only from an understanding of the transition process itself, but also to highlight trends in any episode of structural change. These trends are also common to regions in the old member states, such as in Ireland, the Italian Mezzogiorno, Spain and the UK.

Much remains to do to develop the microeconomic foundations of structural change and its implications on local labour markets. A non-exhaustive list of issues on which future research should focus is as follows: a) theoretical and empirical models of structural change; b) causes and consequences of industrial restructuring; c) changes in the occupational and skill structure of employment; d) the role of labour market institutions in causing labour market frictions.

\section{B. Regional Job and Worker Turnover}

According to the well-known Krugman hypothesis, the higher is the degree of labour turnover, the lower is the unemployment rate across countries. As Blanchard and Summers (1986) claim, a higher degree of cyclicality of the hiring rate is behind fluctuations in the United States unemployment rate. Burda and Wyplosz note that European countries differ in terms of the degree of cyclicality of hiring and firing rates. While some EU countries follow US trends, others, instead, have a cyclical firing rate. Layard, Nickell and Jackman (1991) summarise this research partly confirming the hypothesis that a low job finding rate is behind high unemployment rates, due to the increase in long-term unemployment and its persistent impact on average unemployment.

Translating the Krugman hypothesis to a regional level, high unemployment regions should be those regions where the degree of job finding is lower. Low unemployment regions, in turn, are those where the process of job creation is boosting. This hypothesis 
has also been at the core of the debate on regional unemployment in transition countries (for a survey, see Ferragina and Pastore, 2005).

Some authors (such as Boeri and Scarpetta, 1996; Boeri, 2000; the World Bank, 2001; Rutkowski, 2003) see high local unemployment as a consequence of low labour market dynamism. In fact, high unemployment would concentrate in rural areas, where a small number of job opportunities would force jobless people towards nonemployment (unemployment or inactivity) or the hidden economy (Boeri and Garibaldi, 2003).

Other authors, such as Newell and Pastore (2006), find evidence that unemployment regions are those where the degree of worker turnover is higher, not lower. Lehmann and Walsh (1999) also argue that labour turnover is linked to the level of human capital. Where human capital is interchangeable, workers do not oppose restructuring, which takes place generating unemployment, but also fast output recovery.

Ferragina and Pastore (2005) suggest the existence of an empirical law: the high degree of labour turnover in high unemployment regions is caused by industrial restructuring. Therefore, demand side and industrial policy might be more effective than labour supply policy. Vice versa, when low unemployment rates is related to low labour turnover, then labour supply constraints are behind high unemployment. In this case, supply side policy such as a reduction in passive income support and training policy are the solution to boost job finding by non-employed workers.

This might also hold in old member states where unemployment rate imbalances are dramatic. In the case of Italy, for instance, Contini and Trivellato (2006) find that the traditionally high unemployment regions in the South have a higher (not a lower) degree of turnover compared to low unemployment regions in the North. They argue that high unemployment might be caused not by the hardship of individual workers in finding jobs, but rather by a persistently higher degree of structural change in the South. This might be explained, in turn, by the government's failure to intervene, the low level of social capital and the high crime rate in the Mezzogiorno.

It would be of great interest for the understanding of these important regional issues to consider applying the Krugman hypothesis at a regional level. It would be relevant to address this issue in a systematic way at a regional level. Pertinent studies would be most welcome. A non-exhaustive list of issues on the agenda is as follows: a) theoretical 
and empirical models of regional labour market and/or job flow; b) aggregate and individual level determinants of job finding and separations; c) impact of labour turnover on regional unemployment; d) ties of labour turnover with the business cycle.

\section{Is Migration Reducing or Reinforcing Regional Unemployment Differences?}

Blanchard and Katz (1992) find that labour mobility, as driven by the need to escape unemployment in depressed areas rather than by higher wages in booming regions, has been decisive in achieving regional convergence in unemployment rates across the United States. However, Decressin and Fatas (1995) suggest that in old member states (if any) unemployment convergence across regions was achieved through an increase in inactivity rates in high unemployment regions.

OECD (1995) and Bornhorst and Commander (2006) note that the available information on labour mobility in new member states points to very low interregional flow, which further declined during transition. Gross migration rates are similar to those typical of low mobility EU countries, such as Spain and Italy. As a consequence, the net migration flow is positive in low unemployment regions, as would be expected, but the rate is low and therefore insufficient to compensate large unemployment differentials (see also Rutkowski and Przybila, 2002; and Kertesi, 2000; Boldrin and Canova, 2001; 2003).

Fidrmuc (2004) adds that gross migration, both inbound and outbound, is more sizeable in developed than in peripheral regions, suggesting that migration might contribute to increasing, not reducing regional differentials, by pooling high skill workers in developed regions and separating them from depressed regions.

The debate has also addressed the issue of factors hindering internal migration. The research on the wage curve suggests that wages do respond to local labour market conditions (Blanchflower and Oswald, 1994; 2001; 2005). An interesting consideration relative to the Italian Mezzogiorno is whether there is a wage curve in Italy and whether wage differentials are able to generate sufficient incentives for regional migration (Lucifora and Origo, 1999; Devicienti, Maida and Sestito, 2003).

What is the reason for low interregional mobility in Europe? In the early 1990s, together with linguistic and cultural differences, the high cost of housing and a poorly 
functioning rental market were decisive factors in the EU. In transition countries, these were also the consequence of several factors, such as the dominance of owner-occupied housing, the lack of clarity over property rights and the absence of long-term housing finance. Nonetheless, there is currently no systematic analysis of these factors.

In addition, Boeri (2000) and Rutkowski and Przybila (2002) also ascribe low labour mobility to differences in reservation wages by skill and the mismatch between the unskilled workers residing in high unemployment regions and the demand for skilled work in low unemployment areas. In rural areas, the low-skilled unemployed tend to flow to non-participation, rather than to unemployment, which occurs in urban areas. These studies (Bornhorst and Commander, 2006; Huber, 2004) suggest that low participation rates might be the way by which transition countries will absorb negative shocks in the long-run, as in the case of old member states depicted in Decressin and Fatàs (1995).

These studies confirm the extraordinary similarity of the causes and consequences of regional unemployment in old and new member states and call for research able to confirm or reject these similarities. A non-exhaustive list of issues is as follows: a) the driving forces of capital and labour mobility, and commuting; b) the consequences on regional unemployment; c) the consequences of brain drain and remittances; d) the existence and size of the wage curve.

\section{Is there a Regional Dimension of gender differences?}

The early literature studying gender differences in the labour market on the eve of economic transition was mainly focused on wage differentials, returns to education, and their evolution over time. A recent paper by Munich, Svejnar and Terrell (2005) phrases the question as: “Is women's human capital valued more by markets than by planners?” Other related questions were: What role did pervasive welfare systems exert to prevent gender differences in the communist period? How would increasingly hard budget constraints on both the state administration and the private sector affect female wages?

As noted, among others, in Atkinson and Micklewright (1992), Katz (1997; 2002), Ogloblin (1999), Brainerd (2000), Paci and Reilly (2004), Joliffe and Campos (2005), and Pastore and Verashchagina (2005), under central-planning the system of wage and 
price setting was aimed at equalising wages for all, requiring in fact that both adults in every family would have to work in order to maintain a basic standard of living. At the same time, women had a wide range of rights and privileges at work, such as fully paid maternity leave. Moreover, large state enterprises provided kindergartens, schools and health care facilities for common use. As a consequence, in many centrally planned economies, female labour market participation was high and gender pay gaps low in comparison to many Western economies. However, there were also grey areas, particularly horizontal and vertical segregation.

The process of economic transition in new member states is drastically changing the working profiles of women, re-assessing their lifetime decisions in such matters as when and whether to start a family and whether to participate in tertiary education and/or seek gainful employment. The determinants of such changes would be privatisation of state-owned enterprises (Paci and Reilly, 2004) or the simple process of liberalisation of wage setting mechanisms and a general weakening of the employment protection legislation in the labour market (Brainerd, 2000; Munich, Svejnar and Terrell, 2005).

These changes suggest that women are going to experience the same problems in labour market participation typical of old member states. There is an implication that a decisive aspect of structural change is increasing female unemployment and inactivity. In backward regions in old and new member states unskilled and less motivated women are the weakest group when firms have to reduce employment. On the other hand, the process of tertiarisation seems to favour a feminisation of the labour market. However, especially in backward regions, the expansion of services is slower and is therefore unable to offset the exclusion and marginalisation of less skilled women.

A number of studies in the ensuing literature have tested the hypothesis whether employment reduction was random or whether it was distributed in an asymmetric way against low-skilled, low-motivated women. The usual procedure has consisted of estimating returns to education corrected for sample selection mechanisms. Discussion is on-going on the right instruments to identify the parameters in the selection equation (Orazem and Vodopivec, 1995; 1997; 2000; Saget, 1999; Ogloblin, 1999; Jolliffe, 2002; Pastore and Verashchagina, 2005). 
We expect that the future literature will provide contributions able to shed new light on this important dimension of regional imbalances. A non-exhaustive list of issues is as follows. a) comparative research should study the impact of the liberalisation and privatisation processes on welfare systems, poverty and fertility; b) an interesting comparative research question is whether because of privatisation, only the most skilled women remain in the state sector, while low skill women tend to go to the private sector, causing an increased risk of job loss; c) an increasingly important link between old and new EU regions is the growing feminisation of migration for the provision of personal care facilities. Is there a link between the marginalisation of women in the East and the reduction of the welfare state in the West? d) assessing the impact of different welfare systems and policy instruments recently introduced in old and new member states to ease female access to the labour market.

\section{E. Human Capital as a Factor of Regional Convergence}

The accumulation of human capital is one of the major determinants of economic growth and development (Mankiw, Romer and Weil, 1992). In the last decades, theoretical and empirical literature have analysed this issue in depth providing interesting and innovative results. On the wake of these results, new studies have recently focused more specifically on the role of human capital accumulation in spurring growth and convergence between regions. The aim of this session is to describe the latest results of studies on this issue, and more generally on the role of human capital accumulation as a key determinant of economic development and as a means to enhance both absolute and relative convergence.

Discussion is also quickly developing on the mechanisms through which human capital might cause or, conversely, hinder regional convergence. Generalizing the Nelson and Phelps catch-up model of technology diffusion, Benhabib and Spiegel (1994; 2002) claim that cluster is more realistic than absolute convergence because human capital is not only a productive factor, but also an engine of technological innovation. They show that education plays an important role in the catch-up process. A recent strand of literature also suggests that human capital concentration in urbanised regions is an important competitive factor to attract FDI in advanced sectors and reduce 
the cost of restructuring, as the case of Ireland and of several transition countries has shown (Lehamnn and Walsh, 1999; Newell, Pastore and Socha, 2002; Barry, 2003; Walsh, 2003; Fazekas, 2003).

Moreover, Izushi and Huggins (2004) find that those European regions with a higher level of investment in tertiary education also tend to have a larger concentration of ICT sectors and research functions. These regions have low unemployment rates. Di Liberto and Symons (2003), World Bank (2004) and Newell (2006), among others, note a strong negative correlation between regional unemployment rates and the share of workers with a high level of education in Italy and in Poland.

Complementarity between high technology industries and human capital generates persistence in unemployment differentials with respect to depressed rural areas. And this result may be reinforced by migration and commuting flows, as noted in Firdmuc (2004).

Moretti (2004) finds evidence of social returns to human capital in more developed urban regions in the USA. Causing economies to scale, this would tend to reinforce regional imbalances. However, Jurajda (2005) fails to find evidence of such economies of scale in the case of the Czech Republic.

A non-exhaustive list of issues on which to develop research is as follows: a) the effects of human capital on regional per capita income, and on convergence (or divergence) among regions; b) the ability of human capital concentration to attract FDI; c) theoretical models and empirical studies assessing the social returns to human capital.

\section{F. The Impact of Trade and FDI on Regional Labour Markets}

Can trade expansion help EU backward regions step up the pace of job creation? This is a complex issue, often discussed in policy debate, but still neglected in scientific literature (Suedekum, 2003). Overman and Puga (2002) and Puga (2002) argue that international trade and inflow of capital from abroad tend to reinforce, not to weaken the existing pattern of unemployment. In other words, consistently with the postkeynesian hypothesis of cumulative causation and the New Economic Geography' theories of location with economies of scale, trade and FDI are factors of regional divergence, not convergence. 
In fact, despite the short-run costs of adjustment to trade liberalization, in a number of new member states that successfully integrated into global markets, export-led growth has eventually brought large employment dividends. However, due to the strong polarisation of FDI, employment dividends have been localised in more advanced, urbanised regions (Fazekas, 2000; 2003; Newell, Pastore and Socha, 2002).

Several old and new member states find it difficult to make trade a driver of employment creation and growth. This holds particularly for countries, such as Italy, Spain and Greece, whose exports are concentrated in low value added, slow-growing products, poorly linked to global production networks and FDI flow. Indeed, previous evidence suggests that while the impact of trade expansion on employment is highly significant in countries that are large FDI recipients, trade adds little to job creation in countries that receive only small amounts of FDI.

Future research should address the following questions. After controlling for other structural determinants of employment, is there a positive medium-term relationship between international trade and FDI openness and employment? Is this relationship verified whatever the level of development and for trade in manufacturing as well as in services? To meet the employment challenge, along with continuing trade liberalization, companion policies would need to strengthen the investment climate and upgrade the quality of trade-related services, so as to improve the attractiveness of countries as a place to invest. Which factors are able to boost FDI expansion? After the emphasis on macroeconomic stabilisation, a new growing body of literature is focusing on corporate governance, institutional microeconomic framework, social capital, and crime rates.

A non-exhaustive list of issues is as follows: a) the employment dividends of exportled growth; b) the labour market impact of trade and FDI; c) economic and institutional determinants of FDI at a local level; d) the quality level of trade in goods and services.

\section{G. Hidden Economy and Hidden Employment: Micro and Macroeconomic Implications}

As stressed by Schneider and Enste (2000), and the papers included in the recent Economic Journal symposium (EJ vol. 109, 1999, see Thomas, Bhattacharyya, Tanzi, 
Giles etc.), the underground economy is a sizeable and increasing phenomenon both in terms of output produced and labour input employed in all economies.

The size of underground production, as a percentage of GDP, ranges between 8-9\% for the United States to 12-14\% for France, Great Britain and Germany, and grows up to 22-27\% for Belgium, Spain, Italy and Portugal. Data available for Eastern European countries point out that the share of underground economy is also quite large (Boeri and Garibaldi, 2006; Guariglia and Kim, 2006; Reilly and Kristic, 2006).

The size of the underground economy is a difficult question because reported estimates differ depending on the methodological approach adopted (direct approach, indicator approach and model approach) and on the definition of underground economy. There is no universal agreement on the use of the following definitions: illegal economy, unreported economy, unrecorded economy (see, among others, Schneider and Enste, 2000; Feige, 1989; Thomas, 1992, 1999).

Although the size and implications of informal economic activity vary for different economies, there are common underlying determinants. The most important causes are the burden of tax and social security contributions, the institutional setting for detection, and productivity shocks (see, Tanzi, 1982, 1999; Feige, 1989; Frey and Pommerehne, 1984; Giles, 1999 among others).

However, what is particularly interesting, other than the cyclical behaviour of the underground components (output and employment) and its relation with the "market" (official) components (e.g. Busato and Chiarini, 2004), are the implications that an economy with these characteristics has for fiscal policy.

Advances in research should address countless policy questions. For instance: Does tax evasion and underground economy mitigate the distortionary impact of fiscal policies? Does a restrictive (expansionary) tax change lessen the drop (rise) of aggregate production? Do tax evasion and the informal economy offer a channel for self-insuring income and consumption patterns from distortions generated by fiscal policy? Which is the dynamic mechanism involving: consumption-labour supply, consumption-capital stock, labour supply-leisure, formal-informal labour and production and their consequences in terms of policy reactions.

\section{H. National and EU Regional Policy}


Old and new member states experience remarkable regional inequalities (Decressin and Fatas, 1995; Elhorst, 2003; Ferragina and Pastore, 2005; Bornhorst and Commander, 2006), in spite of inefficient national and EU regional policy. The EU imposes strong constraints on the introduction of fiscal incentives on a territorial basis as it is considered in opposition with competition law.

Despite the deflationary effect of EU monetary policy, especially after the introduction of the Euro, the expenditure for Structural and Cohesion Policy still represents a small share of the overall EU budget, mainly absorbed by the Common Agricultural Policy. Past experience of the implementation of EU regional policy has had few success stories. And the eastward enlargement will put further constraints on the EU budget.

Boldrin and Canova (2001; 2003) have questioned the need itself of EU regional policy, suggesting that it is totally ineffective in reducing regional disparities. Regional policy should therefore be abolished or conceived only as a redistributive tool to transfer wealth from rich to poor regions.

This position has provided fodder for debate. On the one hand, some scholars have attempted to quantify the impact of EU regional policy on regional convergence (see, among others, Garcia-Solanes and Maria-Dolores, 2002; Basile, de Nardis and Girardi, 2003). On the other hand, others have suggested that EU regional policy should be based on new growth and new economic geography theories. It should be relaunched on the basis of the fact that funds should be carefully spent, increasing the local level of human and social capital, of expenditure in research and development, and of infrastructures (Martin, 2003).

Much emphasis has been put on the comparison of successful implementation of EU regional policy. The case of Ireland has stimulated a good deal of attention (Barry, 2003).

A non-exhaustive list of issues that deserve careful analysis is as follows: a) the impact of the eastward enlargement on the institutional framework and actual implementation of EU regional policy; b) the impact of Structural and Cohesion Funds on local productivity and income; c) case studies of good or bad implementation of regional policy. 


\section{Benefit Systems and their Interaction with ALMP}

Income support and/or pro-active schemes have been at the core of the debate on old and new member states as instruments to facilitate labour turnover and ease the social consequences of structural change. In the Aghion and Blanchard (1994) model, unemployment benefits play an important role, that of a temporary pit stop during the reallocation process. Conversely, Boeri (2000) claims that passive income support from the State has made unemployment persistent.

Only since the late 1990s, when transition seemed to have become irreversible and state budgets were suffering dramatic imbalances, the debate has shifted from the issue of gradualism versus shock therapy to that of the optimal design of labour market institutions. Two streams of literature have emerged. Echoing an on-going debate in mature market economies (OECD, 1994; and the ensuing literature), some scholars (Boeri, 2000) started pointing at passive schemes not only as a threat to financial and monetary stability, but also as a disincentive to work and, therefore, a factor for slowing down reforms. Boeri (2000) claimed that the right sequence for implementation of nonemployment benefits should be the opposite of that actually followed: governments should have started from low passive income support schemes to facilitate the flow from the state sector to non-employment and back to employment in the private sector. Only at a later stage, when unemployment was really involuntary, governments should have provided income support to the losers of transition, namely those who were actually not employable in the private sector.

Other scholars (Micklewright and Nagy, 1999; 2002) advocated that the sequence of reforms was correct and that income support schemes in the early stages of transition were indeed necessary to help people bear the dramatic early stages of the transformation.

There is widespread consensus on the fact that a shift from passive to pro-active schemes is necessary to boost the job finding rate and reduce the unemployment rate. As Boeri and Lehmann (1999) note, if skill mismatch is mainly responsible for low outflows from unemployment, then offering training and retraining courses to the unemployed might mitigate the problem. Active labour market policy is also called for 
reducing the gap of work experience between youths and adults. Fiscal incentives for hiring the long-term unemployed, on-the-job training and a number of other schemes are becoming more and more common all over Europe, although evaluation of their net impact on job finding rates is not always positive (Martin, 2000; Peters et al., 2004; Kluve, 2005; OECD, 2006).

In this context, since pension reforms need to be urgently implemented in many old and new member states, papers exploring the available options and able to suggest possible solutions are particularly welcome.

A non-exhaustive list of issues is as follows: a) conceptual comparison of passive, active and welfare-to-work policy across countries and regions; b) the effects of the implementation of the Lisbon Agenda; c) comparative analysis of welfare systems; d) micro-economic analysis of the gross and net impact of pro-active schemes. 


\section{References}

Aghion, Phlippe and Olivier Blanchard (1994), “On the Speed of Transition in Central Europe”, NBER Macroeconomics Annual, 283-320.

Atkinson A. - Micklewright J. (1992), Economic Transformation in Eastern Europe and the Distribution of Income, Cambridge University Press, Cambridge.

Barry, F. (2003), “European Union Regional Aid and Irish Economic Development”, in Funck, B. and L. Pizzati (2003, eds.), op. cit.: 135-152.

Basile, R., S. de Nardis, A. Girardi (2003), "Dinamiche di sviluppo nel centro e nella periferia d’Europa”, Rivista di Politica Economica, 93(7/8): 89-134.

Benhabib, Jess \& Spiegel, Mark M., 1994. "The role of human capital in economic development evidence from aggregate cross-country data", Journal of Monetary Economics, 34(2): 143-173.

Benhabib, Jess \& Spiegel, Mark M., 2005. "Human Capital and Technology Diffusion", in Philippe Aghion \& Steven Durlauf (ed.), Handbook of Economic Growth, ed. 1, vol. 1, ch. 13: 935-966.

Berthold, N. und R. Fehn (2003): Unemployment in Germany - Reasons and Remedies, CESifo Working Paper, No. 871.

Blanchard, O. J. and L. F. Katz (1992), "Regional Evolutions”, Brookings papers on Economic Activity, 1: 1-75.

Blanchard, O. J. and Summers L. (1986), "Hysteresis and the European Unemployment Problem”, NBER Macroeconomics Annual, Ch. 1: 1-78.

Blanchflower, D. G. and A. J. Oswald (1994), The wage curve, MIT Press, Cambridge, MA.

Blanchflower, D. G. (2001), "Unemploymemt, Well-being and Wage curves in Eastern and Central Europe", Journal of the Japanese and International Economies, 15(4): 364-402.

Blanchflower, D.G. and D. Obswald (2005), “The Wage Curve Reloaded”, NBER wp, n. 11238

Boeri, T. (2000), Structural Change, Welfare Systems, and Labour Reallocation. Lessons from the Transition of Formerly Planned Economies, Oxford University Press, Oxford.

Boeri, T. and P. Garibaldi (2006), "Shadow Sorting", NBER Macroeconomic Annual, forthcoming.

Boeri, T. and H. Lehmann (1999), "Introduction. Unemployment and Labour Market Policies in Transition Countries”, Journal of Comparative Economics, 27(1): 1-3.

Boeri, T. and S. Scarpetta (1996), "Regional Mismatch and the Transition to a Market Economy”, Labour Economics, October, 3(3): 233-254.

Boldrin, M., F. Canova (2001), "Inequality and Convergence in Europe's regions. Reconsidering European Regional Policy”, Economic Policy, 32: 205-245.

Boldrin, M. and F. Canova (2003), "Regional Policies and EU Enlargement”, in B. Funck and L. Pizzati (eds.), op. cit.

Bornhorst, F. and S. Commander (2006), "Regional Unemployment and its Persistence in Transition Countries”, Economics of Transition, 14(2): 269-288.

Brainerd, E. (2000), "Women in Transition: Change in Gender Wage Differentials in Eastern Europe and FSU”, Industrial and Labour Relations Review, 54(1): 139-162.

Busato, F. e Chiarini, B. (2004), "Market and Underground Activities in a Two-Sector Dynamic Equilibrium Model”, Economic Theory, 23(4): 831-861.

Caballero, R. J. and M. L. Hammour (1994), “The Cleansing Effect of Recessions”, American Economic Review, December, 8(5): 1350-1368.

Carlin, W. and C. Mayer (1992), "Restructuring Enterprises in Eastern Europe”, Economic Policy, 7(15): 311-352.

Caroleo, F. E. and S. Destefanis (2006, eds.), The European Labour Market. Regional Dimensions, Physica-Verlag, Heildelberg. 
Caselli, Francesco, Gerardo Esquivel, and Fernando Lefort. (1996), "Reopening the Convergence Debate: A New Look at Cross-Country Growth Empirics," Journal of Economic Growth, 1(3), 363-390.

Contini, B. and U. Trivellato (2006), Eppur si muove. Dinamiche e persistenze nel mercato del lavoro italiano, Il Mulino, Bologna.

Decressin, J. and Fatàs, A. (1995), "Regional Labour Market Dynamics in Europe”, European Economic Review, 39(9): 1627-1655.

Devicienti, F. A. Maida and P. Sestito (2003), "Nominal and Real Wage Rigidity: An Assessment Using Italian Microdata”, LABORatorio R. Revelli WP n. 33 (www.labortorino.it/workingpapers/wp33.htm).

Di Liberto, A. and J. Symons (2003), “Some Econometric Issues in Convergence Regressions”, Manchester School, 71(3): 293-307.

Eeckhout, Jan and Boyan Jovanovic, (2000), “Knowledge Spillovers and Inequality”, American Economic Review, 92(5): 1290-1307.

Elhorst, J. P. (2003), “The Mystery of Regional Unemployment Differentials. Theoretical and Empirical Explanations”, Journal of Economic Surveys, 17(5): 709-748.

Fazekas, K. (2000), "Impact of Foreign Direct Investment Inflows on Regional Labour Markets in Hungary”, SOCO Project Paper 77c, Vienna: Institute for Human Sciences.

Fazekas, K. (2003), "Effects of Foreign Direct Investment on the Performance of Local Labour Markets. The Case of Hungary", Budapest working papers, n. 3.

Feige, E.L. (1989, ed.), The Underground Economies: Tax Evasion and Information Evasion, Cambridge University Press, Cambridge.

Ferragina, A.M. and F. Pastore (2005), "Mind the Gap: Unemployment in the New EU Regions", forthcoming in Journal of Economic Surveys (also available as IZA DP, n. 1565, April).

Fidrmuc, J. (2004), "Migration and Regional Adjustment to Asymmetric Shocks in Transition Economies", Journal of Comparative Economics, 32(2): 230-247.

Frey, Bruno S \& Pommerehne, Werner W, 1984. "The Hidden Economy: State and Prospects for Measurement”, Review of Income and Wealth, 30(1): 1-23.

Funck, B. and L. Pizzati (2002, eds.), Labour, Employment and Social Policy in the EU Enlargement Process. Changing Perspectives and Policy Options, World Bank, Washington, D.C.

Funck, B. and L. Pizzati (2003, eds.), European Integration, Regional Policy and Growth, World Bank, Washington, D.C.

Gara M. (2001), The Emergence of Non-Monetary Means of Payment in the Russian Economy, Post-communist economies, 13(1): 5-39.

Garcia-Solanes, I. and R. Maria-Dolores (2002), “The Impact of European Structural Funds on Economi Convergence in European Countries and Regions”, in Meeusen, W. and J. Villaverde (eds.), Convergence Issues in the European Union, Edward Elgar, Aldershot: 334-358.

Giles, David E A, 1999. "Measuring the Hidden Economy: Implications for Econometric Modelling”, Economic Journal, 109(456): F370-80.

Guariglia, A. and B.Y. Kim (2006), "The Dynamics of Moonlighting in Russia”, The Economics of Transition, 14(1): 1-45.

Huber, P. (2004), “Intra-National Labour Market Adjustment in Candidate Countries”, Journal of Comparative Economics, 32(2): 248-264.

Izushi, H. and R. Huggins (2004), "Knowledge competitiveness and productivity in three global poles: analysing structural variation across Europe, the United States and Asia”, Regional Productivity Forum Seminar, Regional Studies Association, 15 January, London

Jolliffe, D. (2002), "The Gender Wage Gap in Bulgaria: A Semi-parametric Estimation of Discrimination”, Journal of Comparative Economics, 30(2): 276-295. 
Jolliffe, D. and H.F. Campos (2005). "Does market liberalisation reduce gender discrimination? Econometric evidence from Hungary, 1986-1998”, Labour Economics, 12(1): 1-22.

Jurajda, S. (2005), “Are There Increasing Returns to Local Concentration of Skills”, IZA-EBRD Conference on: "Labour Market Dynamics, the Role of Institutions and Internal Labour Markets in Transition and Emerging Market Economies”, University of Bologna.

Katz, K. (1997). Gender, Wages and Discrimination in the USSR: A Study of a Russian Industrial Town, Cambridge Journal of Economics, 21(4): 431-452.

Katz, K. (1998). "Where there no returns to education in the USSR? Estimates from Sovietperiod household data”, Labour Economics, 6(3): 417- 434.

Kertesi, G. (2000), "Migration and Commuting: Two Potential Forces Reducing Regional Inequalities in Economic Opportunities?", SOCO Project Paper 77a, Vienna: Institute for Human Sciences.

Kluve, J. (2005), "Study on the Effectiveness of ALMPs”, RWI Essen.

Layard, R., Nickell, S. and Jackman, R (1991), Unemployment. Macroeconomic performance and the labour market, Oxford University Press, Oxford.

Lehmann, H. and P. P. Walsh (1999), "Gradual Restructuring and Structural Unemployment in Poland: A Legacy of Central Planning”, LICOS DP, n. 78, Katholieke Universiteit Leuven.

Lucas, R Jr (1988), “On the Mechanics of Development Planning”, Journal of Monetary Economics, 22(1): 3-42.

Lucifora, C. and F. Origo (1999), “Alla ricerca della flessibilità: Un’analisi della curva dei salari in Italia”, Rivista italiana degli economisti, 4(1): 3-35.

Mankiw, N Gregory \& Romer, David \& Weil, David N, 1992, “A Contribution to the Empirics of Economic Growth”, The Quarterly Journal of Economics, 107(2): 407-37.

Marani, Ugo (2006), The Economics of the Unified Germany, Novus Campus, Naples.

Marelli, E. (2006), "Regional employment dynamics in the EU: structural outlook, comovements, clusters and common shocks”, in: F.E. Caroleo e S. De Stefanis (op. cit.).

Martin, J.P., (2000), "What works among active labour market policies: Evidence from OECD countries' experiences, OECD Economic Studies, 30, 79-113.

Martin, P. (2003), "Public Policies and Economic Geography", in Funck, B. and L. Pizzati (2003, eds.), op. cit.

Micklewright, J. and G. Nagy (1999), "Living Standards and Incentives in Transition: The Implications of Exhausting UI Entitlement in Hungary”, Journal of Public Economics, 73(3): 297-319.

Micklewright, J. and G. Nagy (2002), "The Informational Value of Job Search Data and the Dynamics of Job Search: Evidence from Hungary", Acta Oeconomica, 52(4): 3999-419.

Moretti, E. (2004), "Estimating the Social Return to Higher Education: Evidence From CrossSectional and Longitudinal Data", Journal of Econometrics, 121(1-2): 175-212.

Munich, D., J. Svejnar, K. Terrell (2005), “Is women's human capital valued more by markets than by planners?”, Journal of Comparative Economics, 33(2): 278-299.

Newell, A. (2006), "Skill Mismatch and Regional Unemployment in Poland", in Caroleo, F.E. e S. Destefanis (eds.), op. cit.

Newell, A., F. Pastore and M. Socha (2002), "Comparative Advantages, Job Destruction and the Regional Pattern of Polish Unemployment”, Acta Oeconomica, 52(2): 187-204.

Newell, A. and F. Pastore (2006), "Regional Unemployment and Industrial Restructuring in Poland”, Eastern European Economics, 44(3): 5-28.

OECD (1994), “The OECD Jobs Study: Evidence and Explanations”, OECD, Paris.

OECD (1995), The Regional Dimension of Unemployment in Transition Countries. A Challenge for Labour Market and Social Policies, OECD, Paris.

OECD (2006), "Boosting Jobs and Incomes: Policy Lessons from Reassessing the OECD Job Strategy”, OECD, Paris. 
Ogloblin,C. (1999), "The gender earnings differentials in the Russian Transition economy”, Industrial and Labour Relations Review, 52(4), 602-627.

Orazem, P.F. and Vodopivec, M. (1995), "Winners and Losers of Transition: Returns to Education, Experience, and Gender in Slovenia”, World Bank Economic Review, 9(2): 201-230.

Orazem, P.F. and Vodopivec, M. (1997) "Value of Human Capital in Transition to Market: Evidence from Slovenia”, European Economic Review, 41(3-5), 893-903.

Orazem, P.F. and Vodopivec, M. (2000) "Male-Female Differences in Labour Market Outcomes during the Early Transition to Market: The Case of Estonia and Slovenia", Journal of Population Economics, 13(2): 283-303.

Overman H.G. and D. Puga (2002), "Regional Unemployment Clusters", Economic Policy, 17(34): 115-148.

Paci, P. and Reilly, B. (2004), "Does Economic Liberalisation Reduce Gender Inequality in the Labour Market? The Experience of the Transitional Economies of Europe and Central Asia”, World Bank, Washington D.C.

Pastore, F. and Verashchagina, A. (2005), "The Gender Wage Gap in Belarus”, Transition Studies Review, 12(3): 497-511.

Peters, M., R. Dorenbos, M. van der Ende, M. Versantvoort and M. Arendt (2004), "Benefit Systems and their Interaction with Active Labour Market Policies", European Commission, Employment and Social Affairs, Final Report, February.

Pinto, B., V. Drebentsov, and A. Morozov (2000), Give Macroeconomic Stability and Growth in Russia a Chance. Harden Budget Constraints by Eliminating Non-payments, The Economics of Transition, 8(2): 297-324.

Puga, D. (1999), “The Rise and Fall of Regional Inequalities”, European Economic Review, 43(2): 303-334.

Reilly, B. and Kristic (2006), "Purchasing from Informal Markets: Evidence from Serbia", Applied Economics Quarterly, 52(3): 239-264.

Rutkowski, J. and M. Przybila (2002), “Poland: Regional Dimensions of Unemployment”, in B. Funck and L. Pizzati (eds.), op. cit., Chapter XIV, 157-175.

Rutkowski, J. (2003), "Rapid Labour Reallocation with a Stagnant Unemployment Pool: The Puzzle of the Labour Market in Lithuania”, World Bank, Policy Research working paper series, n. 2946.

Saget, C. (1999), “The Determinants of Female Labour Supply in Hungary”, Economics of Transition, 7(3): 575-591.

Schneider, F. and D.H. Enste (2000), "Shadow Economies: Size, Causes and Consequences", Journal of Economic Literature, 38(1): 77-114.

Stiglitz J. E. (2001), Globalisation and its Discontent, Norton and co.

Suedekum, J. (2003), "Increasing Returns and Spatial Unemployment Disparities”, University of Goettingen, discussion paper, n. 117, April.

Tanzi, Vito (1982), "Underground Economy and Tax Evasion in the United States: Estimates and Implication", in Tanzi, V. (ed.) The Underground Economy in the United States and Abroad. Lexington: Lexington Books: 69-92.

Tanzi, V. (1999), Uses and abuses of estimates of the underground economy, Economic Journal, 109(456): F338-347.

Thomas, J. (1992). Informal economic activity, LSE, Handbooks in Economics, London, Harvester Wheatsheaf.

Thomas, J. (1999), “Quantifying the black economy: Measurement without theory yet again?”, Economic Journal, 109 (456): F381-389.

Todaro, M. P. (1969), “A Model of Labour Migration and Urban Unemployment in Less Developed Countries”, American Economic Review, 59(1): 138-148. 
Uzawa, H. (1961), "On a Two-sector Model of Economic Growth: I”, Review of Economic Studies, 29(1): 40-47.

Uzawa, H. (1965), “Optimal Technical Change in an Aggregate Model of Economic Growth”, International Economic Review, 6(1): 117-124.

Yashiv, E. (2006), “U.S. Labour Market Dynamics Revisited”, IZA Bonn, Discussion Paper, n. 2455.

Walsh, P. P. (2003), “The Cyclical Pattern of Regional Unemployment Flows in Poland”, Economic Systmes, 27(2): 155-169.

World Bank (2001), Poland-Labor Market Study: The Challenge of Job Creation, World Bank Country Study, March.

World Bank (2004), Poland. Growth, Employment and Living Standards in Pre-Accession Poland, Report n. 28233. 